\title{
価值システムに基づく視野推定
}

\section{View Estimation Based on Value System}

\author{
高橋 泰岳
Takahashi Yasutake \\ $\underset{\text { Shimada Kouki }}{\text { 皓樹 }}$ \\ 浅田 稔
}

大阪大学大学院工学研究科

Graduate School of Engineering, Osaka University

yasutake@ams.eng.osaka-u.ac.jp, http://www.er.ams.eng.osaka-u.ac.jp/

(同上)

kouki.shimada@ams.eng.osaka-u.ac.jp

大阪大学大学院工学研究科, JST ERATO 浅田共創知能システムプロジェクト
Graduate School of Engineering, Osaka University, JST ERATO Asada Synergistic Intelligence Project

asada@ams.eng.osaka-u.ac.jp, http://www.er.ams.eng.osaka-u.ac.jp/

keywords: view estimation, reinforcement learning, state value, value system

\section{Summary}

Estimation of a caregiver's view is one of the most important capabilities for a child to understand the behavior demonstrated by the caregiver, that is, to infer the intention of behavior and/or to learn the observed behavior efficiently. We hypothesize that the child develops this ability in the same way as behavior learning motivated by an intrinsic reward, that is, he/she updates the model of the estimated view of his/her own during the behavior imitated from the observation of the behavior demonstrated by the caregiver based on minimizing the estimation error of the reward during the behavior. From this view, this paper shows a method for acquiring such a capability based on a value system from which values can be obtained by reinforcement learning. The parameters of the view estimation are updated based on the temporal difference error (hereafter TD error: estimation error of the state value), analogous to the way such that the parameters of the state value of the behavior are updated based on the TD error. Experiments with simple humanoid robots show the validity of the method, and the developmental process parallel to young children's estimation of its own view during the imitation of the observed behavior of the caregiver is discussed.

\section{1.はじめ に}

子どもにとって養育者の視野を推定することは行動理 解 , 行動意図の推定 , 行動獲得の際に重要である. 本論 文において他者の観察を通した行動理解とは, 子どもが 他者の行動を認識し，行動する中で得られる報酬を推測 し，乥して自分自身で光の報酬が得られる行動を再現で きることを意味する . 子どもは養育者からの明示的な指 導がなくても試行錯誤を繰り返すことにより，多くの行 動を学習していく. 子どもにとって感覚と運動のマッピ ングはグローバル座標系ではなく自己中心座標系に基づ いており，幼児や自閉症児にとって養育者と物体の位置 関係の理解は困難であると言われている . Bekkering et al. は幼児にとって, 対面の相手の行動を模倣することが 困難であると報告している [Bekkering 00] .これは，他 者と物体の位置関係の理解，すなわち視野変換の能力が 生得的ではなく発達の過程で獲得される能力であること を示唆している。

子どもによる行動学習は食べ物を食べる喜び，おもちゃ で遊ふ檪しさなどの動機付けによるものと考えられる . 目 標に到達すると報酬を感じ，報酬を得るために試行錯誤
を繰り返すことにより行動学習を行っている．期待され る報酬と実際に受け取った報酬の推定誤差と脳のドーパ ミンニューロンの活性には強い相関があるという報告が されており [Hollerman 98] , この推定誤差が子どもの行 動学習に影響していると考えられる .このシステムをモ デル化したものが強化学習である [Sutton 98] .

強化学習はシングルエージェントやマルチェージェント 環境における行動学習の手法として多くの研究がされて いる [Connell 93]. 学習者は先験的な知識を必要とせず， 試行錯誤を繰り返すことで最適な行動を獲得する．最適 行動の獲得 (状態から行動へのマッピングの学習) だけで はなく, 状態価値と呼ばれる将来期待される報酬の減衰 総和の獲得に強化学習は用いられる . 状態価值の推定誤 差は TD(Temporal Difference) 誤差と呼ばれ，学習者は TD 誤差に基づいて状態価値や行動を更新する . Meltzoff は他者の行動，意図，信条を理解するために自分自身の 経験を用いる Like me 仮説を唱えている [Meltzoff 07] . この仮説を強化学習の立場からとらえた場合，学習者は 他者の行動を観察しているとき，乥の行動の報酬及び状 態価値を推定していると考えられる . Takahashi et al. は この考え方を基に他者及び自己の報酬及ひ状態価値の予 
測システムを価值システムと呼び , この価値システムに 基づいた他者行動認識システム [Takahashi 07] 及び観測 を通した行動学習促進メカニズム [Takahashi 08] を提案 している。

子どもが養育者の行動を観察し, 弚の行動を理解し模 倣するためには，養育者からの視野を推定し，養育者の 手の平や物体の軌跡から自身の行動表現へのマッピング し，自分自身の報酬系・価值システムに照らし合わせる 必要がある.この時, 観察時の子どもの視野から自身が 同じ行動を実行するときの視野へのマッピング能力はど のように獲得するであろうか．

模倣学習の従来研究の多く(例えば [Schaal 04, Inamura 04]）は観察される動作を模倣するために，観察者は提示 者の動作の軌跡を世界座標系や提示者自身の関節空間へ 変換し,ジェスチャーや行動を模倣している．一方 Asada et al. [Asada 00, Yoshikawa 01b] はエピポーラ幾何に基 づく視野復元の手法を提案している . また Yoshikawa et al. [Yoshikawa 01a] は自身の視野に基づいた他者の視野 推定の学習手法を提案している.これらの視野変換の学 習は幾何学的拘束と提示者の姿勢推定に基づいており， 基本的に模倣による行動学習とは独立している。

工学的には視野変換は 3 次元空間内での平行移動・回 転・拡大縮小といった座標変換に加えて, 3 次元空間の情 報を 2 次元情報に変換する投影变換の組み合わせで構成 される [田村 02] .この視野変換のパラメータの推定は， 二つの画像における複数の対応点がわかりさえすれば， 兴の間の視野変換行列のパラメータは最小二乗法等で推 定でき, 幼児に見られる視野推定能力の発達を説明でき るモデルになるとは考えにくい .

Meltzoff が提唱している Like Me 仮説 [Meltzoff 07] を強化学習の視点から捉えれば，相手の行動を見て相手 が受け取っているであろう報酬を自分自身の経験に照ら し合わせて予測していると考えられる . Takahashi et al. [Takahashi 07, Takahashi 08] が提案しているように，他 者行動を自分の行動のレパートリーに照らし合わせ , 報 酬を推定することで提示された行動をより深く理解し，認 識することが可能である . 感覚と運動および報酬のマッ ピングはグローバル座標系ではなく自己中心座標系に基 づいていると考えられるので, 他者行動を理解・模倣す るためには模倣する際の自己の視野を推定する能力が必 要である.これまでの議論から，他者行動の観測から自 身の感覚に写像し, 報酬を推定する為の視野推定能力を 獲得させるため, 報酬に基づく行動学習と同樣に, 報酬 の推定誤差を視野推定モデルにフィードバックすること により発達するという仮説が考えられる．

乥こで本論文では, 報酬に基づく行動学習と同樣に，報 酬の推定誤差を視野推定モデルにフィードバックさせる ことにより，視野推定能力が発達するという仮説を提案 し，検証する。具体的には強化学習の枠組みにおける TD 誤差に基づく視野推定の手法を提案し, 報酬の推定誤差
を小さくするように視野推定のパラメータを更新させる ことにより, 視野推定能力が発達するという仮説をヒュー マノイドシミュレータを用いた実験により検証する .

\section{TD 誤差に基づく視野推定}

環境中に行動の提示者と観察者がいると仮定する．観 察者は提示者の行動を観察し, 提示者が行動中に受け取 る報酬と状態価值の予測をするために，提示された行動 を自身が実行しているときの視野を推定する．観察情報 を自己の感覚に写像し, 報酬と状態価値を推定すること で他者の行動を理解するための視野推定を目的とするた め，提示者自身の視野を正確に推定するのではなく，あ くまで提示された行動を自分で行っているときの自分の 視野を推定する.ここで観察者と提示者の位置関係が決 まれば, 視野推定のための変換パラメータは与えられた タスクに依存しない.しかし关の視野変換能力は自身の 身体や行動を基に学習し, 乥こで獲得した視野変換能力 を基に他者行動を観察し, 自己の視野空間にマップする ことで, より深い行動理解ができると考えられる．従っ て, 想定される視野推定能力の為の発達過程は以下の通 りになる 。

(1) 自己の試行錯誤による行動学習

(2) 報酬推定のための視野推定能力学習

(3) 自己感覚系へのマッピングに基づく他者行動の理 解と模倣

自己の試行錯誤による行動獲得は従来から多く強化学習 の分野で研究がなされている. 本論文では (2) の観察に よる視野変換能力獲得に焦点を当てる.視野変換能力が 獲得された後は, この能力を基に観察者にとって新規で ある提示行動の観察を通して自己の視野空間にマップす ることで, 提示行動の理解および模倣が可能となる.

\section{$\mathbf{2} \cdot \mathbf{1}$ 実 験 設 定}

图 1 に実験の外観を表す . 2 体のプレイヤーか数個の物 体があるテーブルの前にいる . プレイヤーは 2 体とも強 化学習に基づき物体へのリーチングの行動を獲得し, 状 態価値を持つ. 行動学習の後, 片方が提示者となり物体 にタッチし，もう片方か観察者となり，提示された行動 を自身で模倣する際の視野を推定する。

\section{$2 \cdot 2$ 状態価值}

エージェントがある状態 $s_{t}$ を起点として方策 $\pi$ に従つ て報酬 $r_{t}$ を受け取るときの状態価値 $V\left(s_{t}\right)$ は，

$$
\begin{aligned}
V\left(s_{t}\right) & =E\left[r_{t}+\gamma r_{t+1}+\gamma^{2} r_{t+2}+\cdots\right] \\
& =E\left[r_{t}\right]+\gamma V\left(s_{t+1}\right) .
\end{aligned}
$$




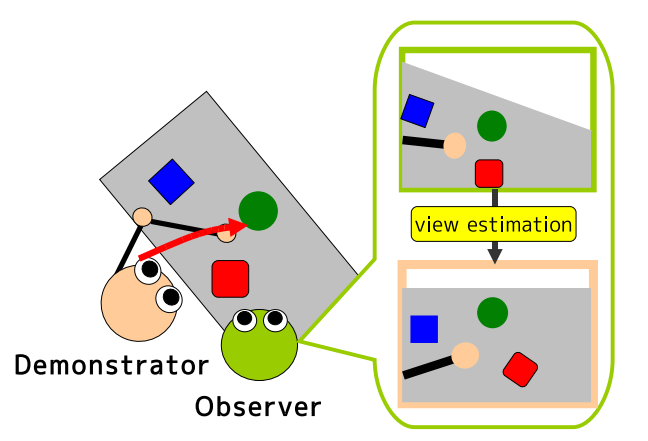

図 1 Scenario of the experiment: Two players are in front of a table. A number of objects are put on the table. One of the players becomes a demonstrator and touches one of the objects. The other player, an observer, tries to estimate the view of self during imitation of the observed behavior.

と定義される . 状態価値 $V\left(s_{t}\right)$ は学習率 $\alpha(0 \leq \alpha \leq 1)$ を 用いて以下のように更新される.

$$
\begin{aligned}
V\left(s_{t}\right) & \leftarrow V\left(s_{t}\right)+\alpha \Delta V\left(s_{t}\right) \\
\Delta V\left(s_{t}\right) & =r_{t}+\gamma V\left(s_{t+1}\right)-V\left(s_{t}\right)
\end{aligned}
$$

このとき求められる状態価値の推定誤差 $\Delta V\left(s_{t}\right)$ を TD 誤差と呼心゙．方策に従って行動をすることで状態か変化 し，報酬が与えられることで状態価値が更新される．こ の状態価値の更新の樣子を図 2(a) に示す. 強化学習の詳 細や弚の応用については, 文献 [Sutton 98]や [Connell 93] を参照されたい .

\section{$2 \cdot 3$ 自己の状態価值に基づく行動理解}

強化学習により状態価值が獲得・更新され，光の結果， 与えられたタスクを達成するための最適行動（状態から 行動へのマップ) が得られる.状態価值の直感的な意味は ゴール状態への近さであり, ゴールに近づけば状態価値も 大きくなる .このことから観察によって推定した他者の状 態価值が上昇したら，他者がゴール状態に近づているこ とが認識できるはずである . Takahashi et al. [Takahashi 07] は獲得済みの自身の状態価值関数に基づき他者の状 態価値を推定することで相手の行動を認識するシステム を提案した . 観察中に自身の獲得した状態価值に基づき 他者の行動を認識する場合は, エージェントは次の手続 きを踏む：

(1) 提示者の行動を観察する

(2) 提示者からの視野を推定する

（3）推定した視野に基づき状態価値を推定する

（4）推定した状態価値の遷移に基づき他者の行動を認 識する

以下では (2)について詳細を述べる .

\section{$2 \cdot 4 \mathrm{TD}$ 誤差に基づく視野推定パラメータの更新}

本節冒頭で述べたが，想定される発達手順はまず自己 の試行錯誤によってあるタスクのための行動を強化学習 によって学習し，次に提示者が行動を見せたときの状態

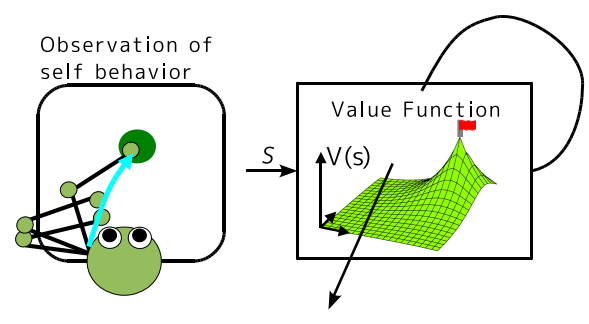

(a)

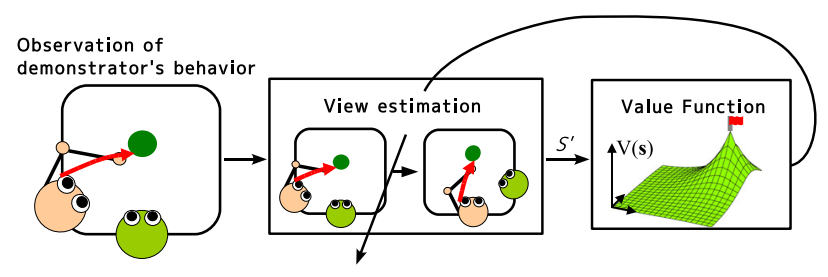

(b)

図 2 (a)Update of state values based on TD error through trial and error, (b)Update of view estimation parameter based on the TD error

価値を自分で獲得した行動を基に推定する . 他者行動の 観察情報から自己の状態価値へマッピングするためには 観察者が観察しているときの視野から自身が同じ行動を 実行するときの視野への変換 , すなわち視野推定が必要 である.ここでは以下の仮定を置く:

・通常の強化学習における仮定と同じように，観測中 の状態遷移はマルコフ過程である .

・提示される行動は観察者にとって既に獲得済みであ る.すなわち，自身て獲得した行動の状態価值は更 新されない.

- 提示者の行動は観察者自身が事前に獲得したリーチ ング行動であり，最終的にリーチングする物体から さかのぼって，提示された動作がどの物体にリーチ ングする動作であつたかを正確に分類できる．

・観察者と提示者の位置は視野推定パラメータの推定 中は固定する .

$\mathrm{TD}$ 誤差に基づく視野推定行列のパラメータ更新の枠 組みを図 2(b) に示す . 図 2(a) に示した状態価值推定のた めの $\mathrm{TD}$ 誤差フィードバックとは異なり，TD誤差を視野 推定行列のパラメータの更新に用いている .

まず，観察者は自己の視野からセンサ情報 ${ }^{o} \boldsymbol{x}$ を取得 する．観察者が提示された行動を模倣したときに取得さ れるセンサ情報 ${ }^{d} \boldsymbol{x}$ は推定行列 ${ }^{d} \boldsymbol{T}_{o}$ を用いて

$$
{ }^{d} \boldsymbol{x}={ }^{d} \boldsymbol{T}_{o}{ }^{o} \boldsymbol{x}
$$

で表される.なお，添え字の $o$ および $d$ は乥れ光れ観察時 (observation)および実行時 (demonstration) を表す . 推定 行列の成分であるパラメータ $\phi_{i j}$ は推定される $\mathrm{TD}$ 誤差 
$\Delta \hat{V}_{t}$ によって更新される.

$$
\phi_{i j} \leftarrow \phi_{i j}-\beta \frac{\partial\left|\Delta V_{t}\right|}{\partial \phi_{i j}}
$$

ただし $, i, j$ はパラメータのインデックス,$\beta(0 \leq \beta \leq 1)$ は更新率である .ここで, 推定される $\mathrm{TD}$ 誤差は

$$
\Delta \hat{V}_{t}=\hat{r}_{t}+\gamma \hat{V}_{t+1}-\hat{V}_{t}
$$

で表現される．ただし，簡単のため

$$
\begin{aligned}
\hat{r_{t}} & =r\left(\hat{s_{t}}\right) \\
\hat{V_{t}} & =V\left(\hat{s_{t}}\right) \\
\hat{s_{t}} & \leftarrow F^{\text {hash }}\left({ }^{d} \boldsymbol{x}_{t}\right)
\end{aligned}
$$

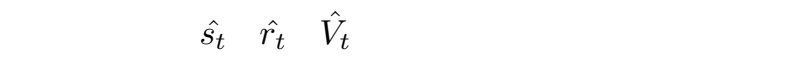
行動を模倣したときに得られると推定される状態，報酬， 状態価値である．ここで， $F^{\text {hash }}$ とはセンサ情報べクト ル ${ }^{d} \boldsymbol{x}_{t}$ を状態 $s \in \boldsymbol{S}$ へと変換するハッシュ関数である.

これまでセンサ情報 $x$ はハッシュ関数によって状態 $s$ に離散化されてきた . 従って状態価值はセンサ情報 $x$ に 対して不連続関数になる. しかし状態価値関数が不連続 であると，式(6)における偏微分か計算できないため，今 回，線形補間により $V(\boldsymbol{x})$ を求めることで状態価値関数 の不連続性の問題を避けている . 式(6)における偏微分 の項に対して式(8) の数値微分を行い, 近似した值を用 いる。

$$
\frac{\partial\left|\Delta \hat{V}_{t}\right|}{\partial \phi_{i j}} \rightarrow \frac{\left|\Delta \hat{V}_{t}\left(\left.{ }^{d} \boldsymbol{x}_{t}\right|^{\phi_{i j}+\delta \phi_{i j}}\right)\right|-\left|\Delta \hat{V}_{t}\left(\left.{ }^{d} \boldsymbol{x}_{t}\right|^{\phi_{i j}-\delta \phi_{i j}}\right)\right|}{2 \delta \phi_{i j}}
$$

ここで, $\left.{ }^{d} \boldsymbol{x}_{t}\right|^{\phi_{i j}+\delta \phi_{i j}}$ と $\left.{ }^{d} \boldsymbol{x}_{t}\right|^{\phi_{i j}-\delta \phi_{i j}}$ は視野推定行列の パラメータ $\phi_{i j}$ を $\delta \phi_{i j}$ だけ増減した時に推定される提示 者のセンサ情報ベクトルである .

\section{$2 \cdot 5$ 視 野 推 定}

エージェントは光れ頭部にカメラを持ち, カメラ 画像上での物体の位置情報を獲得する . 視野推定のため のマッピングは原理的には手法を選ばないが , ここでは 簡単のためにアフィン変換を利用する . 行動を提示され ているときの観察者の視野からの情報を ${ }^{o} \boldsymbol{x}=\left({ }^{o} x,{ }^{o} y\right)$, 観察者が提示された行動を模倣したときに得られると推 定されるセンサ情報を ${ }^{d} \boldsymbol{x}=\left({ }^{d} x,{ }^{d} y\right)$ としたとき，視野 推定行列の成分 $\phi$ を用いて式(9)で表す.

$$
\left(\begin{array}{c}
{ }^{d} x \\
{ }^{d} y \\
1
\end{array}\right)=\left(\begin{array}{ccc}
\phi_{11} & \phi_{12} & \phi_{13} \\
\phi_{21} & \phi_{22} & \phi_{23} \\
0 & 0 & 1
\end{array}\right)\left(\begin{array}{c}
{ }^{o} x \\
{ }^{o} y \\
1
\end{array}\right)
$$

視野推定行列は観察者と提示者の位置関係に依存する . $2 \cdot 4$ 節で仮定したように , 以下の実験では観察者と提示 者の位置は視野推定行列パラメータの推定中は固定する .

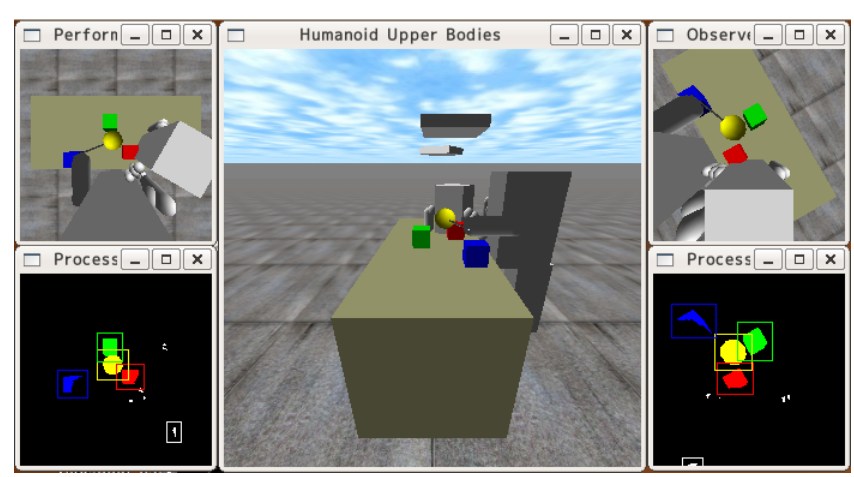

図 3 Viewer of simulator. Top-left: view of a demonstrator. Bottomleft: objects and a palm detection on the camera image of the demonstrator. Center: overview of the experiment with two humanoids and three objects on a table. Top-right: view of an observer. Bottom-right: objects and a palm detection on the camera image of the observer.

\section{3. ヒューマノイドロボットを用いた実験}

\section{$3 \cdot 1$ ヒューマノイドシミュレータ}

図 3 に実験環境の外観を示す.環境中には 2 体のヒュー マノイドロボットとテーブルの上には色の付いた箱が存 在する．ヒューマノイドロボットは 2 自由度で腕を動か すことが出来る. 手の平と物体はロボットの頭部にある カメラにより認識される . テーブルの大きさ, 観察者と 提示者の位置関係は图 5(a) の通りである. 以下の実験で はロボットの視野中心を ${ }^{o} \boldsymbol{x}$ の原点とした .ここで観測者 と提示者は光れ攵れ視野推定能力を獲得する前の幼児と 養育者を想定し，観測者は提示者の体の 3 分の 2 の大き さ，つまり腕の長さも含むリンク長がすべて 3 分の 2 の 長さを持ち, 同じリーチング動作を行う際の軌道と速度 が異なる．また，観察者と提示者の身長差からカメラの 高さが異なり，観察者は提示者よりも近くで行動を観察 するため，提示者の動きが拡大されて見える状況で，ス ケール变動に対する頑強性も持たなくてはならない．

\section{$3 \cdot 2$ 視野推定実験}

まず，観察者は強化学習における状態価値を物体への リーチングを行うことで獲得する . カメラ画像上におけ

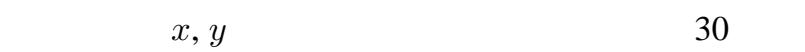

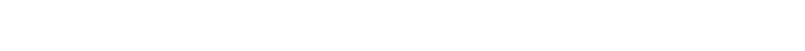
達成された状態に正の報酬 $(+1)$ が与えられ，乥れ以外の 状態では 0 の報酬が与えられる.観察者は光れ光れの物 体へのリーチング行動毎に状態価值関数を用意する. 観 察者の手の平は状態空間において接触できる全ての位置 から一つの物体へのリーチングを行い, 光の行動に対応 した状態価値を学習する。

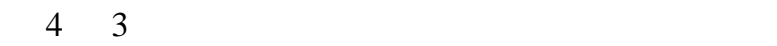
態価値関数を示している.この状態価値関数の形は円錐 状ではなく，緩急のある勾配の山の形をしている .これ は腕の長さや関節角度の影響で可動領域や動作速度に制 


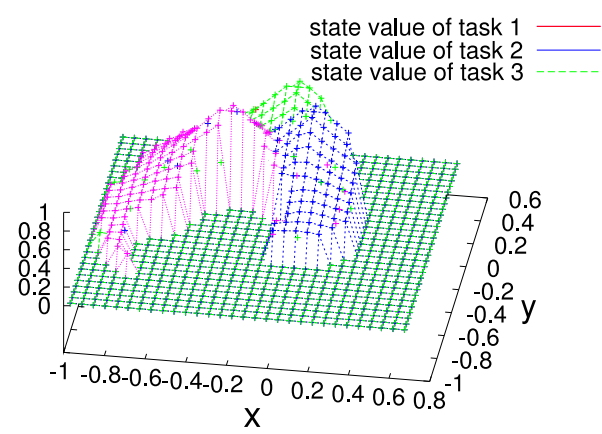

図 4 Three state value functions for reaching behavior to each of three objects

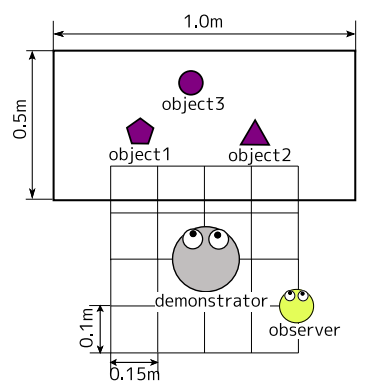

(a) experimental set-up

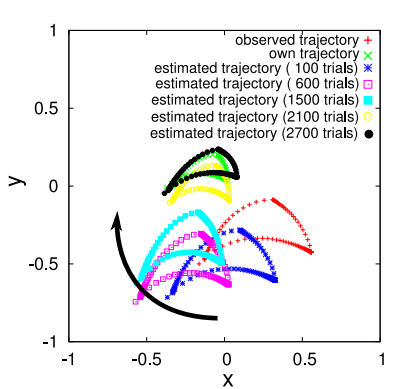

(b) changes of trajectory on estimated view

図 5 Estimation of view of self during imitation of observed behavior: Observer posture is parallel to the demonstrator.

\section{限があるためである .}

次に観察者は提示者の行動を観察する．提示者は樣々 な初期位置から手の平を動かし観察者が事前に獲得した 物体へのリーチング行動を提示し，観察者は近くで観察 することにより獲得済みの状態価值関数から, 状態価值 を推定し視野推定行列を更新する.視野推定行列は単位 行列に初期化している.また, 式(6)の更新率は $\beta=0.01$ に固定する .

推定した視野推定行列を評価するために，いずれの実 験でも提示者が $3 つ の$ 物体に一つずつリーチングする樣 子を観察者に提示し，観察者が提示された行動を自分で 行ったときの自身の視野での軌道を推定し, 弚れを図に

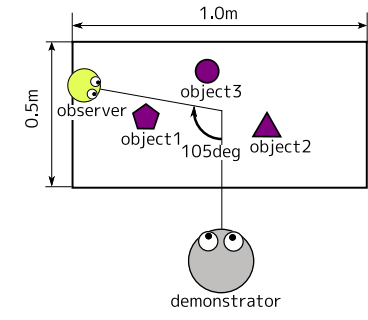

(a) experimental set-up

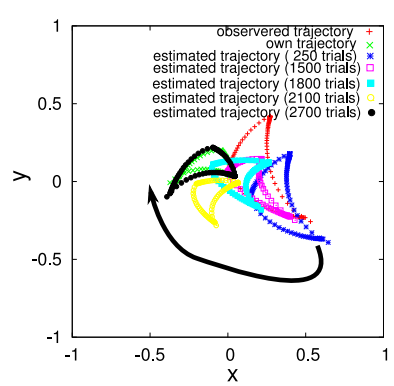

(b) changes of trajectory on estimated view

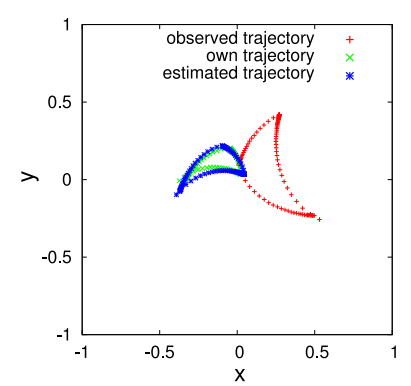

(c) final estimation
図 6 Estimation of view of self during imitation of observed behavior: Observer orients to the demonstrator with 105 degree rotation.

描画する．もし視野推定行列が真の值に近ければ，推定 した軌道が観察者が同じ行動を実行したときの軌道と一 致する .

図 5, 図 6,図 7,図 8 に実験結果を示す.図 5, 図 6 で は，乥れ光れ (a)に観察者，提示者の位置関係の樣子，(b) に視野推定行列の推定過程（視野推定の履歴），(c)に視 野推定パラメータ学習後の推定結果を示す. 図 5(b) は観 察者が提示者の後 $0.1 \mathrm{~m}$, 右 $0.3 \mathrm{~m}$ の位置て推定した視野 推定行列の履歴, 図 6(b) はテーブルの回りで観察者が提 示者から 105 度移動した位置て推定した視野推定行列の 履歴を表している．弚れ光れ 2700 試行の観察を通して 視野推定行列のパラメータを更新させた . 共に観察回数 か増えるにつれ，推定される軌跡が真の值に近づいてお り，提示者の視野を十分に推定していると言える．同樣 の実験を観察者を樣々な位置に配置した場合の結果を図 7 に示す．観察者の位置を提示者に対し平行に移動させ た時の視野推定結果の樣子と推定の成功失敗の分布を图 7(a) 及び図 8(a) に示す. 25 箇所のうち 20 箇所において 推定される軌跡が真の值に近づいていた . 視野推定が失 敗した箇所は観察者の位置が提示者の手の平が見える限 界である前方 $0.2 \mathrm{~m}$ の位置又は後方 $0.2 \mathrm{~m}$ での位置がほと んどであった . また，観察者の位置をテーブルの回りに 移動させた場合 (図 7(b) 及び図 8(b) 参照)，提示者から 105 度移動した位置からでも視野の推定ができ，広い範 囲で正しく推定できることが示された . 


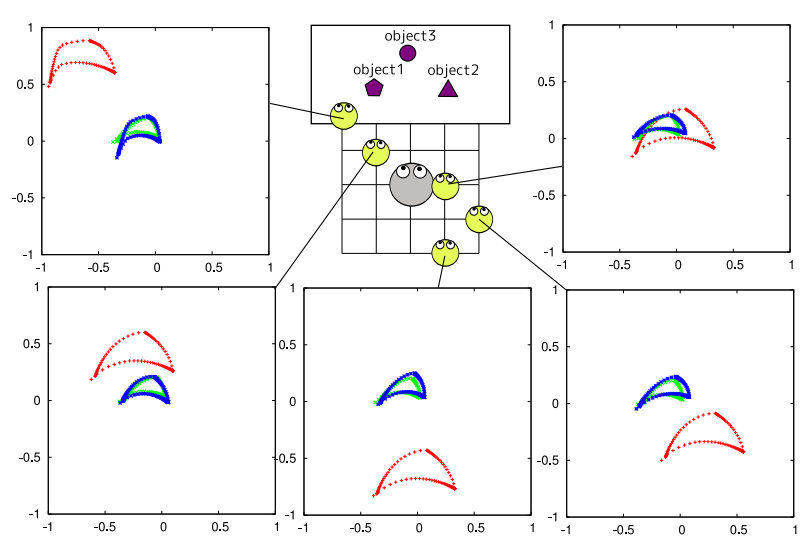

(a) parallel translation

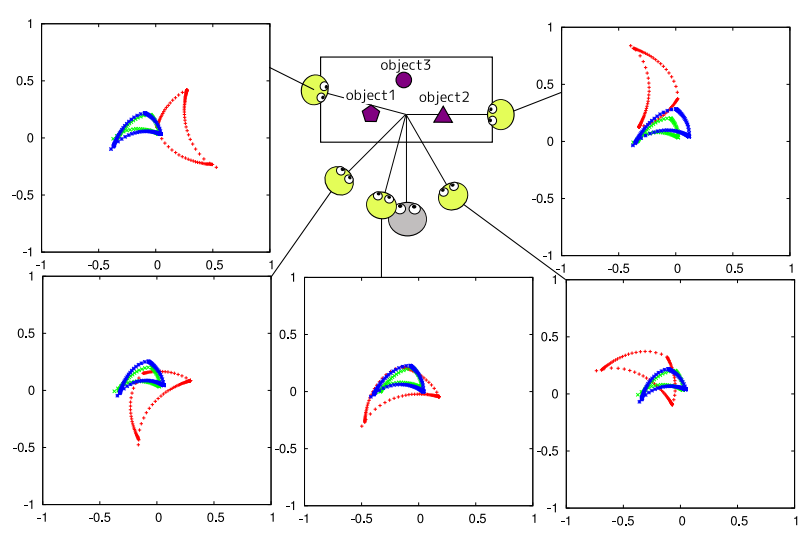

(b) rotational translation

図 7 Final estimated trajectories in various postures. Red, green, and blue curves indicate trajectories in case of observation, estimation, and imitation.

\section{4. ま と め}

本論文では, 視野推定の能力は報酬に基づく行動学習 と同樣に , 報酬の推定誤差を自己から養育者への視野推 定モデルにフィードバックさせることにより発達すると いう仮説を提案し，検証した．Meltzoff が提唱している Like Me 仮説を強化学習の視点から捉え，相手の行動を 見て相手が受け取っているであろう報酬を自分自身の経 験に照らし合わせて予測していると仮定した . 感覚と運 動のマッピングはグローバル座標系ではなく自己中心座 標系に基づているので, 他者行為を理解・模倣するため には視野推定能力が必要である . 他者行動の観測から自 身の感覚に写像し，報酬を推定する為の視野推定能力を 獲得させるため, 報酬に基づく行動学習と同樣に，報酬の 推定誤差を視野推定モデルの更新に利用することにより 視野推定能力が発達するという仮説を提案した . 具体的 には，強化学習における状態価値のパラメータが TD 誤 差によって更新されるように , 視野推定のパラメータも

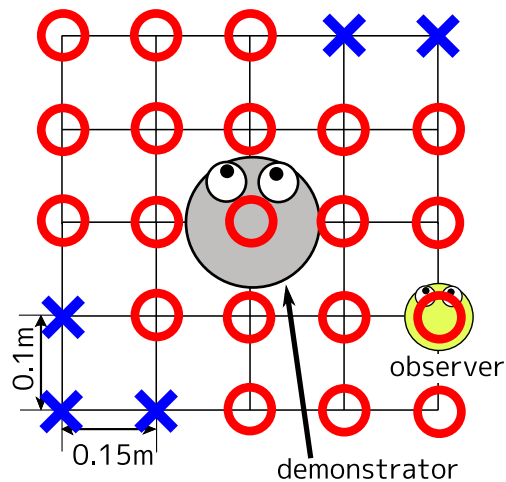

(a) parallel translation

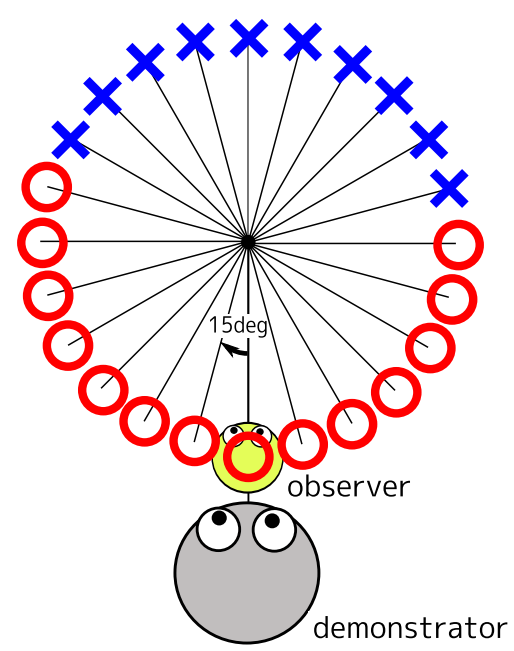

(b) rotational translation

図 8 Success or failure of view estimation in various posture: Circle and cross indicate success and failure, respectively

$\mathrm{TD}$ 誤差によって更新した ・ヒューマノイドシミュレータ を用いた実験によりこの手法の有効性を示した . 本論文 中の実験では観察者と提示者の位置は視野推定パラメー 夕の推定中は固定していたが, 視野推定パラメータに観 察者と提示者の位置関係の情報を反映させる枠組みに拡 張することで, 観察者と提示者の位置関係か変動する環 境下でも視野推定能力が獲得できるものと考えられる .

\section{$\diamond$ 参 考 文 献 $\diamond$}

[Asada 00] Asada, M., Yoshikawa, Y., and Hosoda, K.: Learning by Observation without Three-Dimensional Reconstruction, in Proceedings of Intelligent Autonomous Systems (IAS-6), pp. 555-560 (2000) [Bekkering 00] Bekkering, H. and Wohlschlager, A.: Imitation of gestures in children is goal-directed, The Quarterly Journal of Experimental Psychology, Vol. 53, pp. 153-164 (2000)

[Connell 93] Connell, J. H. and Mahadevan, S.: ROBOT LEARNING, Kluwer Academic Publishers (1993)

[Hollerman 98] Hollerman, J. R. and Schultz, W.: Dopamine neurons report an error in the temporal prediction of reward during learning, 
Nature Neuroscience, Vol. 1, No. 4, pp. 304-309 (1998)

[Inamura 04] Inamura, T., Nakamura, Y., and Toshima, I.: Embodied Symbol Emergence based on Mimesis Theory, International Journal of Robotics Research, Vol. 23, No. 4, pp. 363-377 (2004)

[Meltzoff 07] Meltzoff, A. N.: 'Like me': a foundation for social cognition, Developmental Science, Vol. 10, No. 1, pp. 126-134 (2007)

[Schaal 04] Schaal, S., Ijspeert, A., and Billard, A.: Computational approaches to motor learning by imitation (2004)

[Sutton 98] Sutton, R. and Barto, A.: Reinforcement Learning: An Introduction, MIT Press, Cambridge, MA (1998)

[Takahashi 07] Takahashi, Y., Kawamata, T., Asada, M., and Negrello, M.: Emulation and Behavior Understanding through Shared Values, in Proceedings of the 2007 IEEE/RSJ International Conference on Intelligent Robots and Systems, pp. 3950-3955 (2007)

[Takahashi 08] Takahashi, Y., Tamura, Y., and Asada, M.: Mutual Development of Behavior Acquisition and Recognition Based on Value System, in From Animals to Animats 10 (Proceedings of 10th International Conference on Siulation of Adaptive Behavior, SAB 2008), pp. 291-300 (2008)

[Yoshikawa 01a] Yoshikawa, Y., Asada, M., and Hosoda, K.: Developmental Approach to Spatial Perception for Imitation Learning: Incremental Demonstrator's View Recovery by Modular Neural Network, in Proceedings of the 2nd IEEE-RSA International Conference on Humanoid Robot, pp. 107-114 (2001)

[Yoshikawa 01b] Yoshikawa, Y., Asada, M., and Hosoda, K.: ViewBased Imitation Learning by Conflict Resolution with Epipolar Geometry, in Proceedings of the 2001 IEEE/RSJ International Conference on Intelligent Robots and Systems, pp. 1416-1427 (2001)

[田村 02] 田村秀行 : コンピュータ画像処理, オーム社 (2002)

\section{〔担当委員 : 山口 智浩〕}

\section{8 年 6 月 11 日 受理}

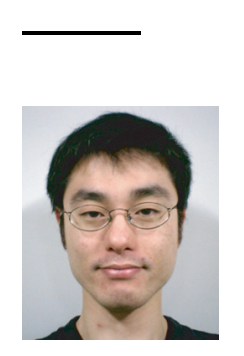

者 紹 介

\section{高橋＼cjkstart泰岳(正会員)}

1994 年大阪大学大学院学研究科博士前期課程修了. 2000 年同大学博士後期課程中退, 同年同大学大学院工学研究科 助手. 現在大阪大学大学院工学研究科知能 - 機能創成工学 専攻助教. この間 2006 年 6 月より 2007 年 9 月までド イツ FraunhoferIAIS 客員研究員 . ロボカップ中型機リー グや知能ロボットの行動獲得に関する研究に従事.人工知 能学会, 日本ロボット学会, 知能情報ファジィ学会などの 会員.

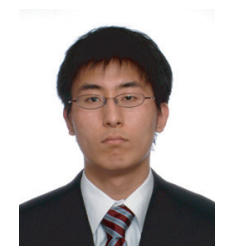

\section{島田 皓樹}

2007 年大阪大学工学部応用理工学科卒業. 同年同大学大 学院工学研究科知能・機能創成工学専攻博士前期課程入学 現在に至る . 知能ロボットの研究に従事 . 日本ロボット学 会会員 .

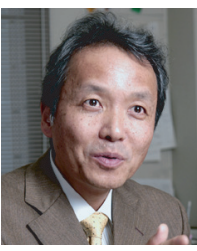

\section{浅田 稔(正会員)}

1982 年大阪大学大学院基礎工学研究科後期課程修了. 同年, 大阪大学基礎工学部助手. 1989 年大阪大学工学部助教授。 1995 年同教授. 1997 年大阪大学大学院工学研究科知能. 機能創成工学専攻教授となり現在に至る.この間，1986 年 から 1 年間米国メリーランド大学客員研究員. 2005 年 9 月より JST ERATO 浅田共創知能システムプロジェクト研 究総括. 認知発達ロボティクスの研究に従事.日本ロボッ 卜学会, 電子情報通信学会, 情報処理学会, 人工知能学会, 日本機械学会, 計測自動制御学会, システム制御情報学会, IEEE R\&A, CS, SMC societies などの会員 